\title{
Stromal cell-derived factor-1 (SDF-1)/chemokine (C-X-C motif) receptor 4 (CXCR4) axis activation induces intra-islet glucagon-like peptide-1 (GLP-1) production and enhances beta cell survival
}

\author{
Z. Liu • V. Stanojevic • S. Avadhani • T. Yano •
}

J. F. Habener

Received: 18 June 2010 /Accepted: 29 March 2011 /Published online: 13 May 2011

(C) Springer-Verlag 2011

\begin{abstract}
Aims/hypothesis The endogenous production of stromal cell-derived factor-1 (SDF-1) in beta cells in transgenic mice attenuates the development of diabetes in response to streptozotocin. Here we propose that beta cell injury induces SDF-1 production, and the SDF-1/chemokine (C-X-C motif) receptor 4 (CXCR4) interaction auto-activates Sdf1 expression, resulting in the autocrine production of SDF-1 by beta cells and the paracrine activation of glucagonlike peptide-1 (GLP-1) production by alpha cells.

Methods SDF-1 production in adult mouse and human islets and rat INS-1 cells was measured in models of beta cell injury. The paracrine actions of SDF-1 on GLP-1 production in alpha cells were explored. The potential synergism between the growth-promoting actions of GLP-1 and the pro-survival actions of SDF-1 on the preservation of cell mass was evaluated by cell viability assays.
\end{abstract}

Electronic supplementary material The online version of this article (doi:10.1007/s00125-011-2181-x) contains supplementary material, which is available to authorised users.

Z. Liu $\cdot$ V. Stanojevic $\cdot$ S. Avadhani $\cdot$ T. Yano $\cdot$ J. F. Habener $(\bowtie)$ Laboratory of Molecular Endocrinology,

Massachusetts General Hospital,

Boston, MA, USA

e-mail: jhabener@partners.org

J. F. Habener

Thier 306,

55 Fruit Street,

Boston, MA 02114, USA

Present Address:

Z. Liu

Sandoz, A Novartis Company,

506 Carnegie Center, Suite 40,

Princeton, NJ 08540, USA
Results In adult islets and INS-1 cells, $S d f 1$ expression was re-induced in response to injury. The interaction of SDF-1 with its receptor on alphaTC1 cells activated protein kinase Akt, stimulated cell proliferation and induced the expression of prohormone convertase $1 / 3$ and the consequent production of GLP-1 in alpha cells. The combination of GLP-1 and SDF-1 additively enhanced both the growth and longevity of INS-1 beta cells.

Conclusions/interpretation The results of these studies suggest that in response to beta cell injury and the ensuing induction of SDF-1, the biological function of alpha cells switches from the production of glucagon to the provision of the local growth factor GLP-1 which, in combination with SDF-1, promotes the growth, survival and viability of the beta cells.

Keywords Alpha cells · Chemokine (C-X-C motif) receptor 4 - Diabetes · GLP-1 - Islets · Prohormone convertase $\cdot$ SDF-1 $\cdot$ Stromal cell-derived factor-1

\author{
Abbreviations \\ CXCR4 Chemokine (C-X-C motif) receptor 4 \\ GLP-1 Glucagon-like peptide-1 \\ JAK Janus kinase \\ PC Prohormone convertase \\ SDF-1 Stromal cell-derived factor-1 \\ STAT Signal transducer and activator of transcription \\ WNT Wingless-related MMTV integration
}

The prevalence of diabetes mellitus is increasing throughout the world [1]. A fundamental underlying cause of diabetes is an inadequate mass of insulin-producing beta cells in the islets of the pancreas, resulting in insufficient 
insulin to meet the body's needs. In type 1 diabetes beta cells are nearly completely destroyed by autoimmunity. In type 2 diabetes, most commonly associated with obesity, beta cell mass is modestly reduced $(\sim 50 \%)$ and the remaining beta cells are functionally impaired by the acquired insulin resistance and resulting hyperlipidaemia and hyperglycaemia, so called gluco-lipotoxic stress. Gluco-lipotoxicity causes increased oxidative stress and shortens the lifespan of beta cells [2,3]. A challenge in the treatment of diabetes is to find a means to preserve or enhance beta cell mass by stimulating the growth of new beta cells, prolonging the lifespan of beta cells, or both.

The architecture of the islets is remarkable in that the mass of insulin-producing beta cells is surrounded by nonbeta endocrine cells: alpha, delta and pancreatic polypeptide-producing cells. In particular, in human islets the alpha cells are mixed in with the beta cells so that $>70 \%$ of beta cells are in heterotypic contact with non-beta endocrine cells, most of which are the alpha cells that express the proglucagon gene $(G C G)$ and produce the hormone glucagon in the islets [4]. This close proximity of endocrine cells to one another in the islets is highly suggestive of intra-islet autocrine and paracrine regulatory interactions among the different endocrine cell types [5].

Stromal cell-derived factor-1 (SDF-1; also known as chemokine [C-X-C motif] ligand 12 [CXCL12]) is a small peptide chemokine that regulates many essential biological processes, including stem cell motility, cardiac and neuronal development, neovascularisation and tissue repair and regeneration [6]. In particular, SDF-1 is produced in reactive stromal tissue in response to injuries of the liver [7] and heart [8], where it is believed to recruit bonemarrow-derived somatic stem cells involved in tissue repair [9]. Injury to the mouse pancreas in response to the transgenic overexpression of IFN $\gamma$ activates production of SDF-1 in duct and stromal tissues [10]. In earlier studies we demonstrated that the SDF-1 receptor, chemokine (C-X-C motif) receptor 4 (CXCR4), is produced in the adult mouse pancreas. However, in adult islets the production of SDF-1 is restricted to vascular endothelial and stromal cells and is not detected in beta cells [11]. The forced endogenous production of SDF-1 in beta cells in transgenic mice (RIPSDF-1) attenuates the development of diabetes in response to the ablation of beta cells by the administration of streptozotocin. An important and surprising finding was that $6 \mathrm{~h}$ after the administration of a high dose of streptozotocin to cause injury in beta cells, phospho-Akt, a pro-proliferative signal, appeared only in the alpha cells and not in the beta cells [11]. When the islets were examined 2 weeks after the single dose of streptozotocin the alpha cells had nearly completely replaced the beta cells in the islets in the normal mice, but many beta cells had persisted or regenerated in the SDF-1 transgenic mice that produce high levels of SDF-1 in beta cells [11]. These observations suggested the existence of paracrine cross-talk between beta and alpha cells as streptozotocin is known to be a beta cell-specific toxin that does not affect alpha cells $[12,13]$. These findings led to our current hypothesis that injured beta cells might be communicating with alpha cells in the islets via SDF-1/CXCR4 signalling. Further, we showed that SDF-1 exerts cytoprotective actions on islet beta cells, and promotes their survival by the activation of the pro-survival kinase Akt and $\beta$-catenin/transcription factor 7-like 2 (T cell specific, HMG-box) (TCF7L2)mediated wingless-related MMTV integration (WNT) signalling [14]. Likewise, the glucoincretin hormone glucagon-like peptide-1 (GLP-1) stimulates WNT signalling in beta cells resulting in an increase in their proliferation [15].

Here we report that in adult islets and in rat insulinoma INS-1 cells $S d f 1$ expression is re-induced in beta cells in response to injury invoked by cytokines, streptozotocin and thapsigargin. The SDF-1 receptor, CXCR4, is expressed on both alpha and beta cells. The paracrine actions of SDF-1 on its receptor on alpha cells activate protein kinase Akt, stimulate cell proliferation and induce the production of prohormone convertase (PC)1/3 and the consequent production of GLP-1 in alpha cells. GLP-1 predominantly promotes proliferation whereas SDF-1 exerts antiapoptotic actions and promotes survival. We found the combination of GLP-1 and SDF-1 additively enhances both growth and longevity of cultured beta cells and thereby preserves beta cell mass against injury, glucotoxicity and nutrient deprivation.

We propose that injury to beta cells activates the SDF-1/ CXCR4 axis in islets, resulting in the autocrine production of SDF-1 by beta cells and paracrine activation of GLP-1 production by alpha cells. The combination of the local intra-islet actions of GLP-1 and SDF-1 enhances the growth and survival of beta cells. Our findings suggest that SDF-1 agonists may be a means to stimulate the growth of alpha cells and their production of GLP-1 in the local intra-islet environment and thereby stimulate regeneration of injured beta cells in diabetes.

\section{Methods}

Reagents Thapsigargin was obtained from Biomol (Plymouth Meeting, PA, USA). Cytokines, SDF-1 IFN $\gamma$, IL-1 $\beta$ and TNF $\alpha$ were obtained from R\&D Systems (Minneapolis, MN, USA). Exendin-4 (EXD4) and streptozotocin were from Sigma-Aldrich (St Louis, MO, USA)

Culture of INS-1, MIN6 cells and alphaTC1 cells Rat INS-1 cells (obtained from C. Wollheim, Geneva, Switzerland) 
were maintained in RPMI supplemented with $10 \%$ FBS, $1.0 \mathrm{mmol} / 1$ sodium pyruvate, $10 \mathrm{mmol} / 1 \mathrm{HEPES}$, penicillin and streptomycin at $37^{\circ} \mathrm{C}$ under $5 \% \mathrm{CO}_{2}$ and at $95 \%$ humidity. Mouse MIN6 cells (obtained from J. Miyazaki, University of Osaka, Japan) were cultured in DMEM containing 15\% (vol./vol.) FBS. Mouse alphaTC1 cells (ATCC \#2350, American Type Culture Collection, Gaithersberg, MD, USA) were maintained in RPMI supplemented with $10 \%$ (vol./vol.) FBS and 15 mmol/l HEPES.

\section{Isolation of mouse pancreas and immunohistochemistry} Pancreases were removed from mice, fixed in formaldehyde or frozen, and immunostaining was performed on tissue sections as described by Yano et al. [11].

Isolation of mouse islets Mouse islets were isolated from the pancreases of mice according to the standard protocol (see legend to Fig. 2). From each 12-18 week old male C57BL/6J mouse, 200-300 islets were obtained. Dispersed cells were prepared from islets isolated from 20-22 week old male mice for immunochemical studies by digestion of the islets in $0.05 \%\left(\mathrm{wt} / \mathrm{vol}\right.$.) trypsin at $37^{\circ} \mathrm{C}$ for $15 \mathrm{~min}$ with gentle shaking. The dispersed cells were plated on poly-Dlysine-coated slides (BD, Franklin Lakes, NJ, USA) and cultured overnight before treatment and fixation for immunostaining.

Human islets from donors Human islet tissue was obtained from the Integrated Islet Distribution Program (Madison, WI, USA). Use of human tissues was approved by the MGH Human Studies Committee. Dispersed cells were prepared from human islets by incubation in $0.01 \%$ trypsin (wt/vol.)-EDTA for $20 \mathrm{~min}$ at $37^{\circ} \mathrm{C}$.

Treatment of islets and cells with cytokines and thapsigargin Dispersed islet cells or INS-1 cells were cultured in 96 well plates or $10 \mathrm{~cm}$ dishes in the presence of $2 \mathrm{nmol} / \mathrm{l} \mathrm{EXD} 4$ and/or $10 \mathrm{nmol} / 1 \mathrm{SDF}-1$ on a background of nutrient deprivation by serum withdrawal or cell-stress-inducing reagent including thapsigargin $50 \mathrm{nmol} / 1$ or a cytokine cocktail of IL-1 $\beta 50 \mathrm{ng} / \mathrm{ml}, \mathrm{TNF} \alpha 10 \mathrm{ng} / \mathrm{ml}$ and IFN $\gamma$ $50 \mathrm{ng} / \mathrm{ml}$. Cell viability was measured by ATPlite assay (PerkinElmer, Waltham, MA, USA) or cell mass measurement.

Cell mass assay INS-1 cells were cultured for 6 days in media with and without combinations of thapsigargin or cytokines with and without SDF-1 and EXD4. At the end of the incubation the cells were harvested by scrape loading and weighed.

RNA isolation and real-time RT-PCR RNA isolation and real-time RT-PCR were performed as previously reported by Yano et al. and Liu et al. $[11,15]$. For each treatment, all samples were performed in triplicate and the data are presented as ratio of $S d f 1$ (also known as Cxcl12)/Gapdh compared with the normalised control.

Phospho-Akt assay AlphaTC1 cells $\left(5 \times 10^{5}\right.$ cells $\left./ \mathrm{ml}\right)$ were treated with $10 \mathrm{nmol} / 1 \mathrm{SDF}-1$ or vehicle controls for the times indicated. Streptozotocin was dissolved in $50 \mathrm{mmol} / 1$ sodium citrate buffer ( $\mathrm{pH} 4.7)$. Cell lysates were prepared and proteins were analysed on western immunoblots as described earlier by Liu et al. [14, 15]. Protein density on immunoblots was quantified by densitometric analysis using a Kodak Image Station 440 CF (Eastman Kodak, Rochester, NY, USA). The primary antibodies used were phospho-Akt (Ser473) (587F11) monoclonal antibody (catalogue no. 4051; Cell Signaling Technologies, Beverly, MA, USA) and Akt antibody, which recognises Akt1, 2 and 3 (catalogue no. 9272; Cell Signaling Technologies).

GLP-1 and insulin assays GLP-1 content in the culture medium and cell lysates was measured using an ELISA kit from BioVender LLC (Candfer, NC, USA) according to the instruction manual. Insulin content in the culture medium was measured by ELISA kit from Millipore (Billerica, MA, USA) according to the instruction manual.

Cell viability assay Cell viability was measured using the ATPlite one-step assay according to manufacturer's manual (PerkinElmer).

Cell proliferation assay Proliferation of alphaTC1 cells was determined by incorporation of BrdU into newly synthesised DNA of proliferating cells. Cells in 96 well plates were treated with SDF-1 (10 nmol/1) or PBS overnight, then pulse-labelled with BrdU for $4 \mathrm{~h}$. BrdU staining was measured using the DELFIA cell proliferation kit (PerkinElmer).

Immunofluorescent staining of dispersed mouse islet cells Trypsin-treated cells were plated on slides and cultured overnight in RPMI media (Gibco, Grand Island, NY, USA) containing 10\% (vol./vol.) FBS. Cells were treated, washed and fixed in $10 \%$ formalin in PBS for $15 \mathrm{~min}$ at room temperature for fluorescence immunostaining using a rabbit antiserum to mouse $\mathrm{PC} 1 / 3$ (a gift from D. F. Steiner and M. Hara, Chicago, IL, USA) and antisera to insulin (Millipore) and glucagon (SigmaAldrich). A mouse anti-glucagon monoclonal antibody was used and the antiserum to insulin was from guinea pig. Secondary fluorophore antibodies used were Cy2 (green)labelled donkey anti-rabbit $\operatorname{IgG}$ and $\mathrm{Cy} 3$ (red)-labelled donkey anti-mouse $\operatorname{IgG}$ (glucagon) and donkey anti-guinea pig IgG (insulin). Fluorescent images were captured with a Nikon Optiphot 2 microscope using Photometric Cool Snap 
HQ camera (Photometrics, Huntington Beach, CA, USA) and IP Lab 3.6.5 software (Scanalytics, Falls Church, VA, USA).

Statistical analyses Data are presented as the mean \pm SD. Statistical analysis was performed using paired $t$ test. Values of $p<0.05$ were considered statistically significant.

\section{Results}

Neonatal expression of SDF-1 in beta cells is extinguished in the adult pancreas We previously reported that SDF-1 production in islets of the adult mouse pancreas is restricted to the vascular endothelial and stromal cells of the islets. As the SDF-1/CXCR4 axis signalling is implicated in the early developing pancreas [16], we examined neonatal pancreases for the production of SDF-1. We observed robust production of SDF-1 in beta cells of the islets at 3 (Fig. 1a) and 21 days (Fig. 1b) after birth but not in the adult islets at 60 days after birth (Fig. 1c). Notably, the pancreatic islets continue to develop and to remodel for 3-4 weeks after birth [17], suggesting that SDF-1 production in beta cells might be involved in their development and remodelling and that when they become fully differentiated $S d f-1$ expression is suppressed.

Injuries of islets and beta cells induces the production of $S D F-1$ Tissue injury induces regenerative processes that often recapitulate developmental programmes. Therefore, we asked whether injury to beta cells by various means would re-induce the neonatal pattern of SDF-1 production in islets. We subjected isolated mouse islets and human donor islets ex vivo (Fig. 2), and cultured beta cells in vitro to injuries by cytokines, thapsigargin, an inducer of ER stress [14], streptozotocin and hyperglycaemic glucotoxic stress (Fig. 3). In both mouse and human islets, treatment with cytokines (IL-1 $\beta$, TNF $\alpha$, IFN $\gamma$ ) or the inducer of endoplasmic reticulum stress thapsigargin increased levels of $S d f 1$ mRNA. Interestingly, the treatment of human islets with SDF-1 also increased the levels of SDF1 mRNA, indicating that the chemokine SDF-1 acts like the cytokines and induces its own expression in beta cells in islets by an autocrine mechanism (Fig. 2b). To examine actions of injurious agents more directly on beta cells than can be done on islets we then used relatively well-differentiated cultured beta cell lines: MIN6 (mouse) and INS-1 (rat). In both MIN6 (Fig. 3a, b) and INS-1 (Fig. 3c) cells cytokines induced Sdf1 mRNA levels by three- to 15 -fold. Thapsigargin and streptozotocin were less potent than cytokines, increasing Sdf1 mRNA levels by two- to threefold. The addition of AMD3100, a specific antagonist of CXCR4, inhibited the increase in $S d f 1$ mRNA levels induced by SDF-1, indicating that the signalling responsible for activating $S d f l$ gene expression is transduced via the SDF-1 receptor (Fig. 3d). Importantly, the induction of Sdf1 mRNA transcription by cytokines was inhibited by
Fig. 1 SDF-1 produced in the beta cells of the neonatal (postnatal day $[\mathrm{P}] 3$ and $\mathrm{P} 21$ ) but not the adult (P60) mouse pancreas. SDF-1 production and its colocalisation with insulin in mouse islet beta cells at (a) P3 and (b) P21. c P60, adult pancreas. The majority of SDF-1 produced in the adult mouse pancreas is in cells within the interstitium surrounding the ducts and blood vessels in the islets (identified by staining of von Willebrand factor $[\mathrm{vWF}]$ ) a

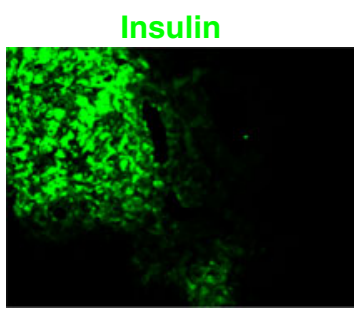

b

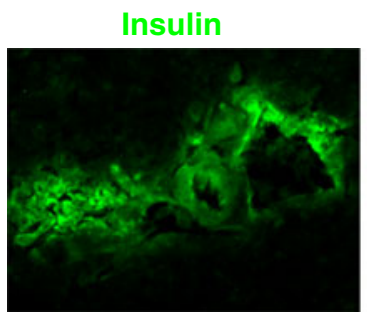

C

Insulin

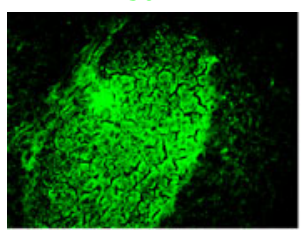

SDF-1

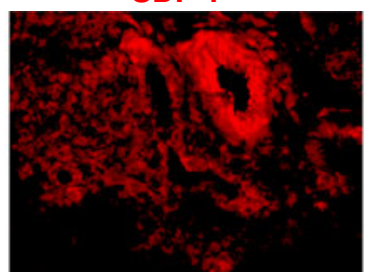

SDF-1

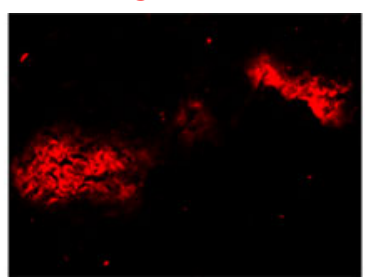

SDF-1

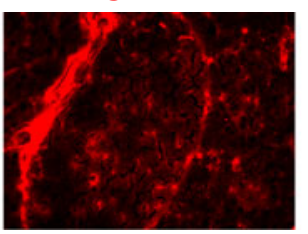

Insulin / SDF-1

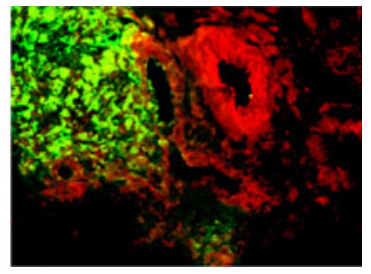

Insulin / SDF-1 / DAPI

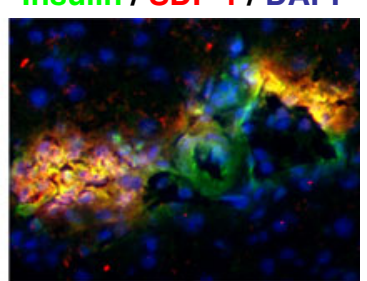

SDF-1 / vWF
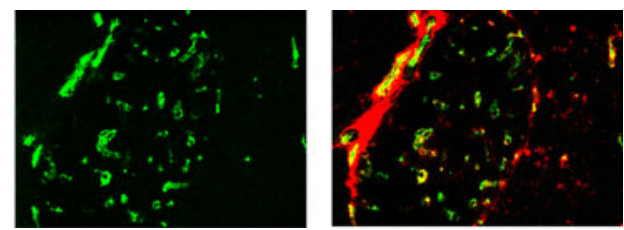

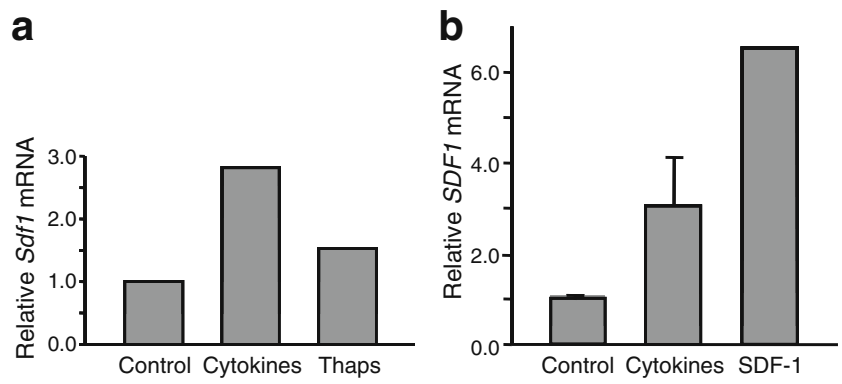

Fig. 2 Beta cell injury induces expression of $S d f 1$ in islets. $S d f 1$ mRNA levels are induced in (a) mouse and (b) human islets by beta cell stress-activating agents. a Cytokines $(50 \mathrm{ng} / \mathrm{ml} \mathrm{IL-1} \beta, 10 \mathrm{ng} / \mathrm{ml}$ $\mathrm{TNF} \alpha, 50 \mathrm{ng} / \mathrm{ml} \mathrm{IFN} \gamma$ ) and $50 \mathrm{nmol} / 1$ thapsigargin were added to mouse islets. b Cytokines and $20 \mathrm{nmol} / \mathrm{l} \mathrm{SDF}-1$ were added to human islets. In all experiments mRNA was extracted from islets and quantificative RT-PCR was performed. Islets were isolated by standard procedures [40]. All values are expressed relative to the value of the control-treated cells. Thaps, thapsigargin

AG490, a potent inhibitor of the Janus kinase (JAK)/signal transducer and activator of transcription (STAT) signalling pathway $[18,19]$, an important known signalling pathway used by CXCR4 in response to SDF-1 (Fig. 3c).

SDF-1 stimulates the proliferation of alphaTC1 cells and induces the production of PC1/3 and GLP-1 Because of our earlier findings that the administration of streptozotocin
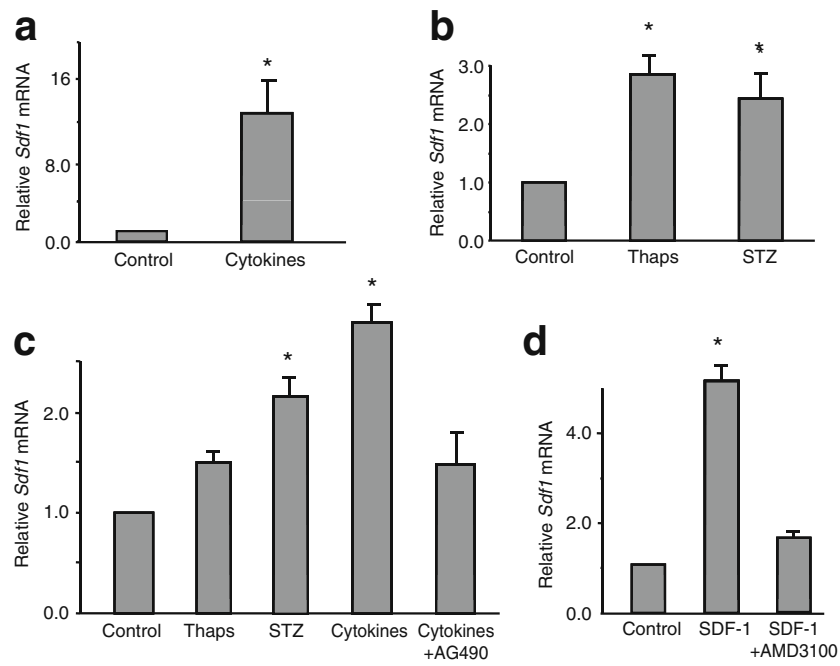

Fig. 3 Beta cell injury induces expression of $S d f 1$ in beta cell lines. MIN6 and INS-1 beta cells were treated with stress/apoptosis inducers. MIN6 cells were treated with: (a) mixtures of cytokines (same concentration as indicated in the Fig. 2 legend), or (b) thapsigargin or streptozotocin. INS-1 cells were treated with: (c) thapsigargin (Thaps), streptozotocin (STZ) or cytokines with and without AG490, an inhibitor of JAK/STAT signalling; or (d) $10 \mathrm{nmol} / 1$ SDF-1 with and without $25 \mu \mathrm{mol} / 1$ AMD3100, an antagonist of the SDF-1 receptor, CXCR4. In all experiments the amount of $S d f 1$ mRNA was measured by quantitative RT-PCR. All values are means \pm SEM $(n=8)$ relative to the value of the control-treated cells. ${ }^{*} p<0.01$ vs control values to mice activates Akt in the alpha and not the beta cells of islets [11] and the reported observation that the administration of streptozotocin to neonatal rats stimulates alpha cell hyperplasia and elevates plasma levels of GLP-1 [20], we wondered whether the SDF-1 induced by streptozotocin in beta cells might act on alpha cells. Therefore, we examined alphaTC1 cells, a well-studied alpha cell line [21, 22], for the presence of the SDF-1 receptor CXCR4. We found robust expression of CXCR4 on alphaTC1 cells (Fig. 4a) and that activation of the cells with SDF-1 stimulated the formation of active phospho-Akt within $2 \mathrm{~min}$ of its application to the cells (Fig. 4b). These findings were of interest because Akt and JAK/STAT signalling are known to activate the expression of $P c 1 / 3[23,24] . \mathrm{PC} 1 / 3$ is required for the processing of proglucagon, the product of the glucagon gene $(G c g)$, to GLP-1 [25]. We therefore examined mouse islets and alphaTC1 cells for their expression of Pcl/3 (also known as Pcskl) and the production of GLP-1 in response to the application of SDF-1. As reported previously [22], we confirmed that

a
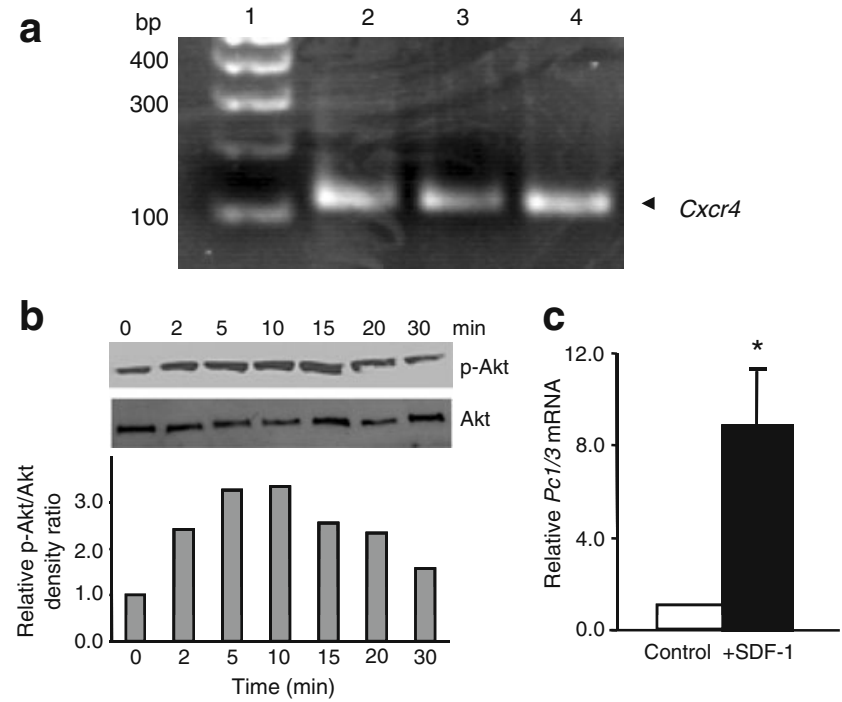

Fig. 4 Beta cell injury activates SDF-1/CXCR4 axis signalling in alpha cells. a The SDF-1 receptor CXCR4 is produced in alphaTC1 cells. Messenger RNA for Cxcr4 is detected in alphaTC1 cells by PCR. The known Cxcr4 expression in MIN6 cells is shown as a control. Lanes: 1, molecular markers; 2, alphaTC1 cells; 3, alphaTC1 cells with disruption of the $P c 2$ gene; 4 , MIN6 cells. bp, base pairs. b SDF-1 activates protein kinase Akt in alphaTC1 cells. Phosphorylated Akt (p-Akt), the active form of Akt, is increased within 2 min after the addition of SDF-1 to the cells. Shown are the phosphoimmunoblot and a semi-quantificative bar graph of the relative ratios of p-Akt to total Akt protein with time after the addition of SDF-1. c SDF-1 induces the expression of $P c 1 / 3$. Shown is the induction of $P c 1 / 3$ mRNA levels in alphaTC1 cells $1 \mathrm{~h}$ after the addition of SDF-1 $(10 \mathrm{nmol} / 1)$ to the cells. No mRNA is detectable in alphaTC1 cells without added SDF-1. White bars, control medium; black bars, SDF-1 added. Values are shown relative to the value of the control-treated cells. Statistical significance is depicted as $* p<0.01$ when compared with control values 
$P c 1 / 3$ is barely detectable by quantificative PCR in alphaTC1 cells (Fig. 4c) and only trace amounts of GLP-1 peptide are detected by a sensitive GLP-1-specific ELISA in alphaTC1 cells (Fig. 5c) and in islets (Fig. 5a, b). The addition of SDF-1 to alphaTC1 cells induced the expression of $P c 1 / 3$ within $1 \mathrm{~h}$ (Fig. $4 \mathrm{c}$ ) and stimulated the production and secretion of GLP-1 in both mouse and human islets (Fig. 5a, b) and in alphaTC1 cells (Fig. 5c). In a similar experiment the production of GLP-1 was unaffected by the GLP-1 receptor agonist EXD4 (data not shown).

To investigate production of $\mathrm{PC} 1 / 3$ in primary mouse alpha cells, dispersed mouse islet cells were prepared and cultured overnight before immunostaining with antisera to $\mathrm{PC} 1 / 3$, glucagon and insulin. Immunocytochemical analyses of alpha and beta cells in dispersed mouse islet cells showed weak, but definite, specific production of $\mathrm{PC} 1 / 3$ in alpha cells compared with stronger production in beta cells (electronic supplementary material [ESM] Fig. 1a, b). Dispersed mouse islet cells were treated with SDF-1 $(100 \mathrm{nmol} / \mathrm{l})$ for $6 \mathrm{~h}$. Examination of several hundred cells by immunocytofluorography with antisera to $\mathrm{PC} 1 / 3$, glucagon and insulin suggested that the intensity of $\mathrm{PC} 1 / 3$ fluorescence increased in alpha cells with the addition of SDF-1 (ESM Fig. 1c). However, the paucity of cells precluded attempts at quantificative assessment of $\mathrm{PC} 1 / 3$ production in alpha cells. It remains possible, however, that the production of $\mathrm{PC} 1 / 3$ in alpha cells is perturbed by the stresses induced in the cells by islet isolation and the enzymatic dispersal of the islet cells. The effect of SDF-1 on GLP-1 production is an important finding because GLP-1 is known to stimulate the growth $[14,26]$ and promote the survival $[27,28]$ of beta cells. The production of GLP-1 locally within the islet could exert short-range tropic actions on adjacent beta cells. The addition of SDF-1 to alphaTC1 cells appears to stimulate their proliferation as determined by BrdU incorporation into the cells in response to SDF-1 (Fig. 5d). This finding suggests that the production of SDF-1 by injured beta cells might be a mechanism for the development of alpha cell hyperplasia seen in mice after the ablation of beta cells by the administration of streptozotocin $[11,12]$.

SDF-1 and GLP-1 additively enhance INS-1 cell mass We next explored potential synergism between the growthpromoting actions of GLP-1 and the pro-survival actions of SDF-1 on the efficacy of the regeneration of beta cell mass in response to beta cell injury (Fig. 6). We hypothesised that the combination of GLP-1 and SDF-1 enhance both

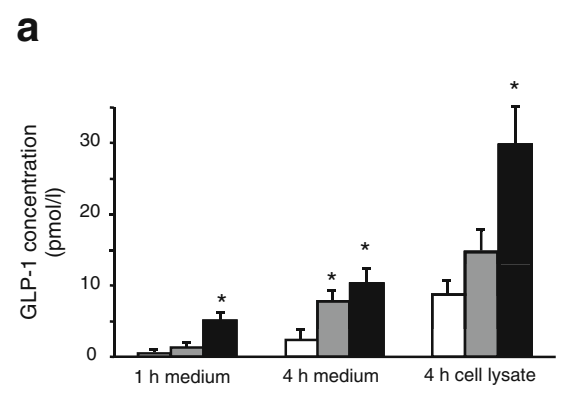

b
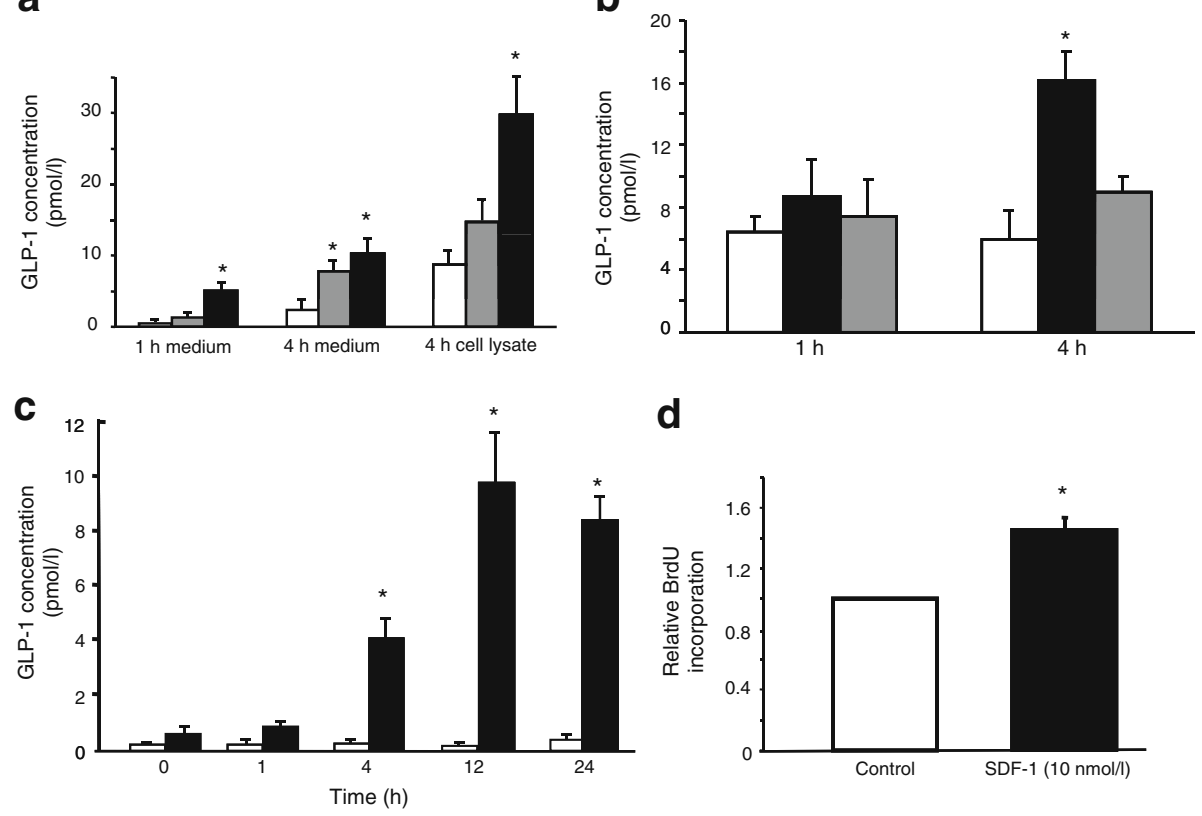

d

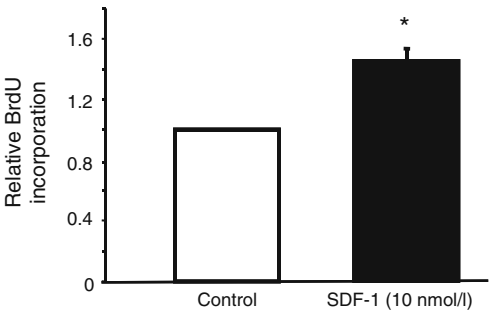

Fig. 5 Cytokines and SDF-1 induce the production of GLP-1 protein in islets and alphaTC1 cells. a SDF-1 and cytokines stimulate the production of GLP-1 protein in isolated mouse islets. White bars, control medium; grey bars, cytokines added (see Methods); black bars, SDF-1 (10 nmol/l) added. b SDF-1 stimulates GLP-1 production in isolated human islets and production is inhibited by the CXCR4 antagonist AMD3100. White bars, control medium; black bars, SDF-1 (10 nmol/1) added; grey bars, SDF-1+AMD3100 added. c SDF-1 stimulates the production of GLP-1 in alphaTC1 cells during a $24 \mathrm{~h}$

incubation and production is not affected by the GLP-1 receptor agonist EXD4. GLP-1 levels were determined by ELISA in islet culture media and in extracts of the islets (cell lysate). White bars, control medium; black bars, SDF-1 (10 nmol/l) added. d SDF-1 stimulates the proliferation of alphaTC1 cells. Cells were incubated with $10 \mathrm{nmol} / 1 \mathrm{SDF}-1$ for $24 \mathrm{~h}$ and relative proliferation was assayed by BrdU incorporation into the cells. White bars, control medium; black bars, SDF-1 added. Values are shown relative to the value of the control-treated cells. ${ }^{*} p<0.01$ vs control values in all panels $(n=8)$ 


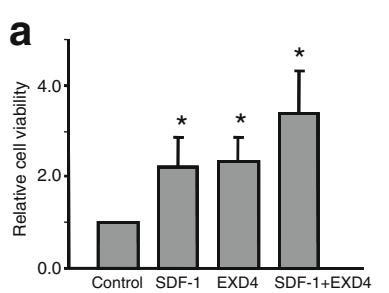

b
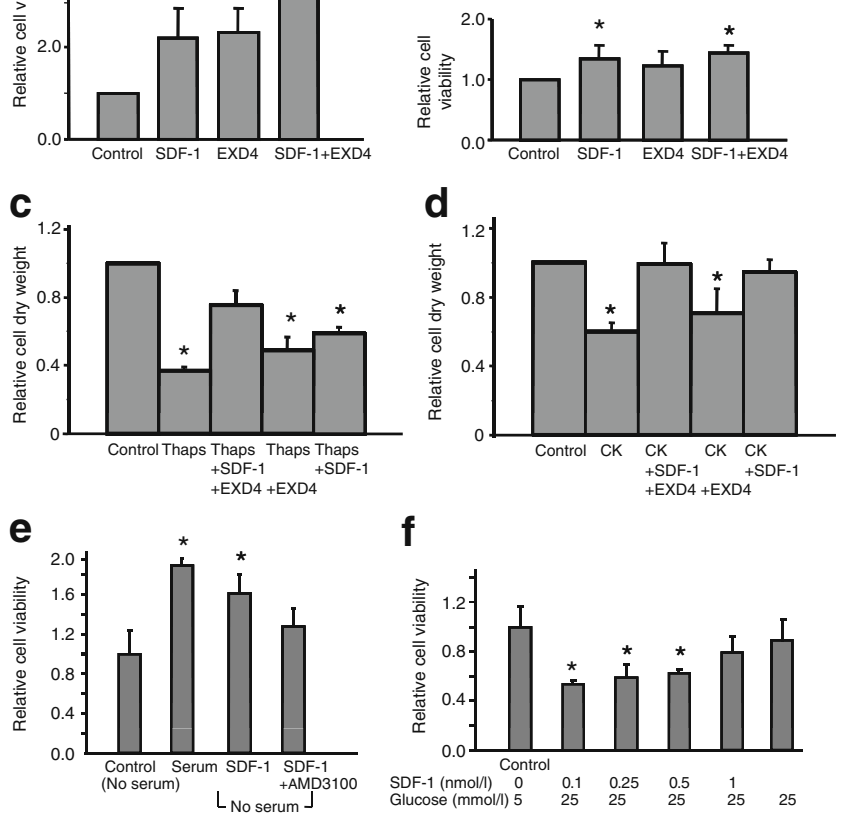

f
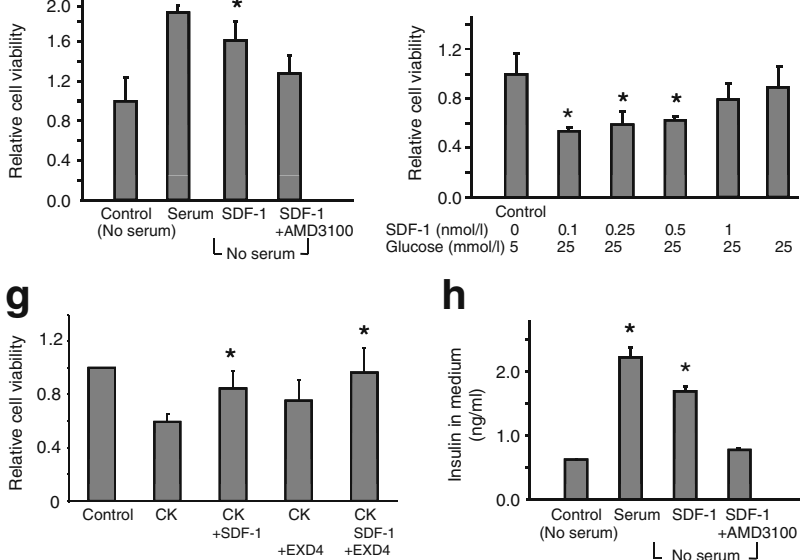

h

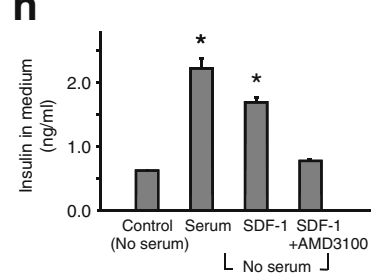

Fig. 6 SDF-1 and the GLP-1 receptor agonist EXD4 act additively to preserve and enhance beta cell mass. INS-1 cells were cultured in 96 well plates in the presence of $2 \mathrm{nmol} / 1 \mathrm{EXD} 4$ and/or $10 \mathrm{nmol} / \mathrm{l} \mathrm{SDF}-1$ on a background of (a) serum deprivation or (b) serum repletion $(0.8 \%)$. EXD4 and SDF-1 were replenished every 2 days. Cell viability was measured 6 days after treatment by ATPlite assay. INS-1 cells treated with (c) thapsigargin or (d) cytokines were incubated with vehicle or $10 \mathrm{nmol} / 1 \mathrm{SDF}-1,10 \mathrm{nmol} / 1 \mathrm{EXD} 4$ or SDF-1+EXD4 for 6 days and their dry weight was then measured. Data are expressed as mass relative to the mass for vehicle treatment. e INS-1 cells were cultured in 96 well plates in the presence of $10 \mathrm{nmol} / \mathrm{l} \mathrm{SDF}-1$ with or without AMD3100 (25 $\mu \mathrm{mol} / 1)$ on a background of nutrient deprivation by serum withdrawal (no serum). f INS-1 cells were cultured in 96 well plates in the presence of increasing doses of SDF-1 on a background of normal $(5 \mathrm{mmol} / \mathrm{l})$ or high glucose concentration (25 mmol/l). Reagents were added at day 0 and day 2 , and 4 days after treatment, cell viability was measured using the ATPlite assay. g Dispersed human islets were cultured in 96 well plates $(\sim 100$ islets/well) in the presence of $2 \mathrm{nmol} / 1 \mathrm{EXD} 4$, and/or $10 \mathrm{nmol} / 1 \mathrm{SDF}-1$ on a background of cytokines (IL-1 $\beta 50 \mathrm{ng} / \mathrm{ml}, \mathrm{TNF} \alpha 10 \mathrm{ng} / \mathrm{ml}, \mathrm{IFN} \gamma 50 \mathrm{ng} / \mathrm{ml}$ ). Cell viability was measured 3 days after treatment by ATPlite assay. The viable beta cell number was enhanced additively by EXD4 and SDF-1. Therefore the combination of GLP-1 and SDF-1 increased human islet cell viability against cytokine-stress-induced cell death. $\mathbf{h}$ For the insulin secretion assay, INS-1 cells were plated in 96 well plates. SDF-1 (2 nmol/1) and AMD3100 were added at day 0 , and the insulin concentration of culture medium was measured at day 6. Statistical significance is depicted as $* p<0.01$ when compared with control values in all panels $(n=6)$. CK, cytokines; Thaps, thapsigargin growth and longevity of INS-1 cells and thereby preserve beta cell mass against ongoing injury. We used the more stable long-acting GLP-1 receptor agonist EXD4. INS-1 cells were cultured in the presence of $2 \mathrm{nmol} / \mathrm{l}$ EXD4 and/or $10 \mathrm{nmol} / \mathrm{l} \mathrm{SDF-1}$ on a background of injury induced by serum withdrawal and repletion (Fig. 6a, b), thapsigargin (Fig. 6c), or cytokines (IL-1 $\beta, \mathrm{TNF} \alpha$, IFN $\gamma$ ) (Fig. 6 d, g). EXD4 and SDF-1 were replenished at 2 days. At 4 days after treatment cell viability was measured by the ATPlite assay (Fig. 6 a, b). In parallel, INS-1 cell mass was assessed at the end of the culture by scrape-harvest and weighing of the cell mass (Fig. 6c, d). Under glucotoxicity ( $25 \mathrm{mmol} / \mathrm{l}$ glucose), SDF-1 protects cell survival in a dose-dependent fashion (Fig. 6f) and in serum deprivation conditions SDF-1 partially restores insulin secretion from INS-1 cells (Fig. 6h). The viability of primary dispersed human islet cells treated with cytokines was also enhanced additively by the co-addition of SDF-1 and EXD4 (Fig. 6g). Importantly, the actions of SDF-1 on cell survival (Fig. 6a) and on insulin secretion (Fig. 6h) in conditions of serum deprivation are inhibited by the SDF-1 receptor antagonist AMD3100.

\section{Discussion}

We demonstrate that when islet beta cells are injured by cytokines, streptozotocin, thapsigargin and glucotoxicity, SDF-1 production resembling neonatal production is reinduced. The SDF-1 receptor CXCR4 is expressed on alpha cells and is capable of activating the Akt protein kinase. Importantly, the apparent paracrine actions of SDF-1 on its receptor in alpha cells stimulate the production of GLP-1 in islets. We further explored the potential synergism between the growth-promoting actions of GLP-1 and the pro-survival actions of SDF-1 on the preservation of INS-1 cell mass, and found that the combination of GLP-1 and SDF-1 additively enhances both growth and longevity of beta cells.

GLP-1, an incretin hormone initially recognised for its glucose-dependent insulin-releasing actions, is now known to stimulate both the proliferation $[15,26]$ and the survival

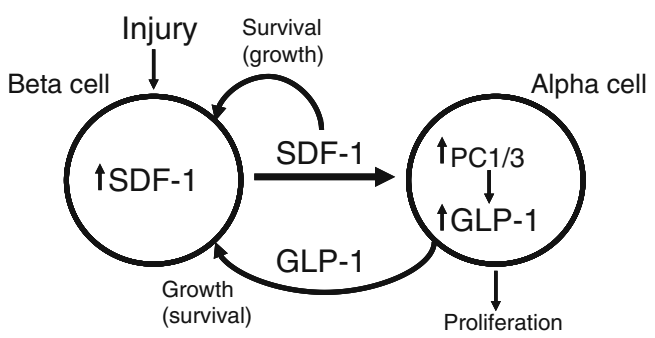

Fig. 7 Model depicting the proposed autocrine and paracrine crosstalk between beta and alpha cells in response to beta cell injury: the $\mathrm{B}>\mathrm{A}>\mathrm{B}$ hypothesis. See text for explanation 
[27] of beta cells. GLP-1 agonists given systemically are currently used to stimulate insulin secretion in type 2 diabetic individuals. Alpha cells normally produce PC2, which cleaves proglucagon to release glucagon, a hormone that stimulates hepatic glucose production to maintain euglycaemia during fasting. GLPs are cleaved from proglucagon by $\mathrm{PC} 1 / 3$, another member of the $\mathrm{PC}$ protein family not normally produced in alpha cells. Activation of $\mathrm{PC} 1 / 3$ production and the ensuing GLP-1 production were recently found in alpha cells of prediabetic NOD mice, pregnant mice, $o b / o b$ mice and $d b / d b$ mice [29]. Therefore the stimulation of GLP-1 production from alpha cells within islets, specifically by SDF-1 agonists, might provide high local paracrine concentrations of GLP-1 for adjacent beta cells at a critical time during their injury and thereby might promote beta cell regeneration. We propose that a mechanism for the induction of GLP-1 production in alpha cells of islets is via the induction of $\mathrm{PC} 1 / 3$ by the paracrine actions of SDF-1. PC1/3 production and resultant GLP-1 production convert the alpha cell from a hyperglycaemiapromoting cell to one that promotes beta cell growth and survival.

In addition to a role for alpha cells in exerting paracrine tropic influences on beta cells via GLP-1 secretion, alpha cells might actually transdifferentiate into beta cells, given the appropriate stimulus. Recent seminal findings by Collombat et al. [30] and Thorel et al. [31] provide proofof-concept evidence that the alpha cell lineage is endowed with an unusual plasticity and that alpha cells can become functional beta cells in response to beta cell injury. Based on our findings, we propose that alpha cells might also play active role in the preservation and regeneration of beta cells in the adult pancreas in response to injury invoked by means such as autoimmunity in type 1 diabetes and glucolipotoxicity in type 2 diabetes. As such, we refer to this mechanism as the $\mathrm{B}>\mathrm{A}>\mathrm{B}$ hypothesis: injured beta cells signal to alpha cells, which in turn signal to beta cells to stimulate their regeneration (Fig. 7). In our model, in response to beta cell injury (resulting in hypoinsulinaemia and hyperglycaemia) the biological functions of the alpha cells switch from regulation of glucose metabolism (glucagon) to providing a local growth factor, GLP-1, which is involved in the regeneration of the injured beta cells. This switch is mediated through the intra-islet signalling mediated by the SDF-1/CXCR4 axis, which has been shown to play an important role in pancreas development [16] and regeneration [11] and, particularly, in the growth and survival of beta cells $[10,11,14]$. The effects of GLP-1-induced protection against apoptosis might be mediated by IGF-1 as GLP-1 is reported to increase the activity of an IGF-1/IGF-1 receptor loop in beta cells [32].

In pathophysiological conditions, such as exposure to sustained high glucose because of the development of insulin resistance in type 2 diabetes, the beta cells increase in number (hyperplasia) in an attempt to produce more insulin to counteract the hyperglycaemia. Likewise, sustained hypoglycaemia induced by the experimental disruption of glucagon signalling, e.g. knockout of the glucagon receptor gene [33, 34], or knockout of the gene encoding PC2, which is required for the post-translational cleavage of proglucagon to produce glucagon [35-37], resulting in impaired gluconeogenesis, leads to marked alpha cell hyperplasia.

Paradoxically, alpha cell hyperplasia also occurs in conditions of insulin deficiency resulting from injury of beta cells, for example in mice given the beta cell toxin streptozotocin $[11,12,37,38]$, or in the NOD mouse in which beta cells are injured by autoimmune attack [39]. By all physiological arguments of feedback regulation of glucagon secretion, hyperglycaemia should suppress glucagon secretion and alpha cell functions, and not cause hyperplasia of the alpha cells. We propose that this paradox of alpha cell hyperplasia might be explained by the fact that in response to beta cell injury (resulting in hypoinsulinaemia and hyperglycaemia) the injured beta cells produce SDF-1 and the activation of the SDF-1/CXCR4 axis in alpha cells adjacent to beta cells in islets. The activation of CXCR4-mediated signalling stimulates alpha cell proliferation and switches the biological functions of the alpha cells from the regulation of glucose metabolism to that of providing local growth factors, such as GLP-1, involved in the regeneration of the injured beta cells. Whether or not SDF-1 stimulates the proliferation of primary alpha cells in vivo or in vitro remains uncertain. Although we have demonstrated increased proliferation of cultured alphaTC1 cells by SDF-1, attempts at demonstrating SDF-1-mediated stimulation of primary mouse and human islet cells in vitro were equivocal because of the sparsity of alpha cells in dispersed mouse islet cell preparations and the rapid ( 1 day in culture) dedifferentiation of dispersed cells prepared from donor human islets. The validation of the hypothesis that SDF-1 might stimulate the growth of alpha cells awaits appropriate studies in vivo, such as using the transgenic RIP-SDF-1 mouse that constitutively expresses $S d f 1$ in islet beta cells [11]. Our results, and the previous study in $P c 2$ (also known as Pcsk2)-null mice [34], demonstrate that the alpha cells are endowed with an unusual plasticity in their abilities to switch their hormone production from glucagon to GLP-1, which has functions within islets proposed to promote the growth and the survival of beta cells.

Acknowledgements We thank K. McManus and L. Brindamour for expert experimental assistance. We thank M. Hara and D. F. Steiner for the generous gift of the $\mathrm{PC} 1 / 3$ antiserum. The studies were 
supported in part by research grants (J. F. Habener) and a postdoctoral fellowship (Z. Liu) from the Juvenile Diabetes Research Foundation and a grant from the Charles H. Hood Foundation of the Medical Research Foundation to Z. Liu.

Duality of interest The authors declare there is no duality of interest associated with this manuscript.

\section{References}

1. van Dieren S, Beulens JW, van der Schouw YT, Grobbee DE, Neal B (2010) The global burden of diabetes and its complications: an emerging pandemic. Eur J Cardiovasc Prev Rehabil 17 (suppl 1):S3-S8

2. Poitout V, Robertson RP (2008) Glucolipotoxicity: fuel excess and beta-cell dysfunction. Endocr Rev 29:351-366

3. Kusminski CM, Shetty S, Orci L, Unger RH, Scherer PE (2009) Diabetes and apoptosis: lipotoxicity. Apoptosis 14:1484-1495

4. Cabrera O, Berman DM, Kenyon NS, Ricordi C, Berggren P-O, Caicedo A (2006) The unique cytoarchitecture of human pancreatic islets has implications for islet cell function. Proc Natl Acad Sci USA 103:2334-2349

5. Stagner JI, Samols E, Bonner-Weir S (1988) Beta-alpha-delta pancreatic islet cellular perfusion in dogs. Diabetes 37:1715-1721

6. Ratajczak MZ, Zuba-Surma E, Kucia M, Reca R, Wojakowski W, Ratajczak J (2006) The pleiotropic effects of the SDF-1-CXCR4 axis in organogenesis, regeneration and tumorigenesis. Leukemia 20:1915-1924

7. Hatch HM, Zheng D, Jorgensen ML, Petersen BE (2002) SDF1alpha/CXCR4: a mechanism for hepatic oval cell activation and bone marrow stem cell recruitment to the injured liver of rats. Cloning Stem Cells 4:339-351

8. Abbott JD, Huang Y, Liu D, Hickey R, Krause DS, Giordano FJ (2004) Stromal cell-derived factor-1alpha plays a critical role in stem cell recruitment to the heart after myocardial infarction but is not sufficient to induce homing in the absence of injury. Circulation 110:3300-3305

9. Kucia M, Reca R, Jala VR, Dawn B, Ratajczak J, Ratajczak MZ (2005) Bone marrow as a home of heterogenous populations of nonhematopoietic stem cells. Leukemia 19:1118-1127

10. Kayali AG, van Gunst K, Campbell IL et al (2003) The stromal cell-derived factor-1alpha/CXCR4 ligand-receptor axis is critical for progenitor survival and migration in the pancreas. J Cell Biol 163:859-869

11. Yano T, Liu Z, Donovan J, Thomas MK, Habener JF (2007) Stromal cell derived factor-1 (SDF-1)/CXCL12 attenuates diabetes in mice and promotes pancreatic beta-cell survival by activation of the prosurvival kinase Akt. Diabetes 56:29462957

12. Li Z, Karlsson FA, Sandler S (2000) Islet loss and alpha cell expansion in type 1 diabetes induced by multiple low-dose streptozotocin administration in mice. J Endocrinol 165:93-99

13. Park IS, Che YZ, Bendayan M, Kang SW, Min BH (1999) Upregulation of clusterin (sulfated glycoprotein-2) in pancreatic islet cells upon streptozotocin injection to rats. J Endocrinol 162:57-65

14. Liu Z, Habener JF (2009) Stromal cell-derived factor-1 promotes survival of pancreatic beta cells by stabilization of beta-catenin and activation of TCF7L2. Diabetologia 52:1589-1598

15. Liu Z, Habener JF (2008) Glucagon-like peptide-1 activation of TCF7L2-dependent Wnt signaling enhances pancreatic beta cell proliferation. J Biol Chem 283:8723-8735

16. D'Amour KA, Agulnick AD, Eliazer S, Kelly OG, Kroon E, Baetge EE (2005) Efficient differentiation of human embryonic stem cells to definitive endoderm. Nat Biotechnol 23:1534-1541
17. Scaglia L, Cahill CJ, Finegood DT, Bonner-Weir S (1997) Apoptosis participates in the remodeling of the endocrine pancreas in the neonatal rat. Endocrinology 138:1736-1741

18. Vila-Coro AJ, Rodríguez-Frade JM, Martín de Ana A et al (1999) The chemokine SDF-1alpha triggers CXCR4 receptor dimerization and activates the JAK/STAT pathway. FASEB J 13:16991710

19. Zhang XF, Wang JF, Matczak E, Proper JA, Groopman JE (2001) Janus kinase 2 is involved in stromal cell-derived factor-1alphainduced tyrosine phosphorylation of focal adhesion proteins and migration of hematopoietic progenitor cells. Blood 97:33423348

20. Thyssen S, Arany F, Hill DJ (2006) Ontogeny of regeneration of beta cells in the neonatal rat after treatment with streptozotocin. Endocrinology 147:2346-2356

21. Webb GC, Dey A, Wang J, Stein J, Milewski M, Steiner DF (2004) Altered proglucagon processing in an alpha-cell line derived from prohormone convertase 2 null mouse islets. J Biol Chem 279:31068-31075

22. Wideman RD, Yu IL, Webber TD, Verchere CB, Johnson JD, Cheung AT, Kieffer TJ (2006) Improving function and survival of pancreatic islets by endogenous production of glucagon-like peptide 1. Proc Natl Acad Sci USA 103:13468-13473

23. Lankat-Buttgereit B, Müller S, Schmidt H, Parhofer KG, Gress TM, Göke R (2008) Knockdown of Pdcd4 results in induction of proprotein convertase $1 / 3$ and potent secretion of chromogranin $\mathrm{A}$ and secretogranin II in a neuroendocrine cell line. Biol Cell 100:703-715

24. Fox DL, Good DJ (2008) Nhlh2 interacts with STAT3 to regulate transcription of prohormone convertase 1/3. Mol Endocrinol 22:1438-1448

25. Wideman RD, Covey SD, Webb GC, Drucker DJ, Kieffer TJ (2007) A switch from prohormone convertase $\mathrm{PC} 2$ to $\mathrm{PC} 1 / 3$ expression in transplanted alpha cells is accompanied by differential processing of proglucagon and improved glucose homeostasis in mice. Diabetes 56:2744-2752

26. Friedrichsen BN, Neubauer N, Lee YC, Gram VK, Blume N, Petersen JS, Nielsen JH, Møldrup A (2006) Stimulation of pancreatic beta-cell replication by incretins involves transcriptional induction of cyclin D1 via multiple signalling pathways. J Endocrinol 188:481-492

27. Hui H, Nourparvar A, Zhao X, Perfetti R (2003) Glucagon-like peptide-1 inhibits apoptosis of insulin-secreting cells via a cyclic 5 '-adenosine monophosphate-dependent protein kinase A- and a phosphatidylinositol 3-kinase-dependent pathway. Endocrinology 144:1444-1455

28. Li Y, Hansotia T, Yusta B, Ris F, Halban PA, Drucker DJ (2003) Glucagon-like peptide-1 receptor signaling modulates beta cell apoptosis. J Biol Chem 278:471-478

29. Kilimnik G, Kim A, Steiner DF, Friedman TC, Hara M (2010) Intraislet production of GLP-1 by activation of prohormone convertase $1 / 3$ in pancreatic $\alpha$-cells in mouse models of $\beta$-cell regeneration. Islets 2:149-155

30. Collombat P, Xu X, Ravassard P et al (2009) The ectopic expression of Pax 4 in the mouse pancreas converts progenitor cells into alpha and subsequently beta cells. Cell 138:449-462

31. Thorel F, Népote V, Avril I, Kohno K, Desgraz R, Chera S, Herrera PL (2010) Conversion of adult pancreatic alpha-cells to beta-cells after extreme beta-cell loss. Nature 464:1149-1154

32. Cornu M, Yang JY, Jaccard E, Poussin C, Widmann C, Thorens B (2009) Glucagon-like peptide-1 protects beta-cells against apoptosis by increasing the activity of an IGF-2/IGF-1 receptor autocrine loop. Diabetes 58:1816-1825

33. Kedees MH, Guz Y, Vuguin PM et al (2007) Nestin expression in pancreatic endocrine and exocrine cells of mice lacking glucagon signaling. Dev Dyn 236:1126-1133 
34. Vuguin PM, Kedees MH, Cui L et al (2006) Ablation of the glucagon receptor gene increases fetal lethality and produces alterations in islet development and maturation. Endocrinology 147:3995-4006

35. Webb GC, Akbar MS, Zhao C, Swift HH, Steiner DF (2002) Glucagon replacement via micro-osmotic pump corrects hypoglycemia and alpha-cell hyperplasia in prohormone convertase 2 knockout mice. Diabetes 51:398-405

36. Vincent M, Guz Y, Rozenberg M et al (2003) Abrogation of protein convertase 2 activity results in delayed islet cell differentiation and maturation, increased alpha-cell proliferation, and islet neogenesis. Endocrinology 144:4061-4069
37. Nie Y, Nakashima M, Brubaker PL et al (2000) Regulation of pancreatic $\mathrm{PC} 1$ and $\mathrm{PC} 2$ associated with increased glucagon-like peptide 1 in diabetic rats. J Clin Invest 105:955-965

38. Jones CW, Reynolds WA, Hoganson GE (1980) Streptozotocin diabetes in the monkey: plasma levels of glucose, insulin, glucagon, and somatostatin, with corresponding morphometric analysis of islet endocrine cells. Diabetes 29:536-546

39. Ogawa N, List JF, Habener JF, Maki T (2004) Cure of overt diabetes in NOD mice by transient treatment with anti-lymphocyte serum and exendin-4. Diabetes 53:1700-1705

40. Lacy PE, Kostianovsky M (1967) Method for the isolation of intact islets of Langerhans from the rat pancreas. Diabetes 16:35-39 